AKUNTABILITAS

Vol. VIII No 3, Desember 2015

P-ISSN : 1979-858X

Halaman $171-190$

\title{
FAKTOR-FAKTOR YANG MEMPENGARUHI KEBERHASILAN PENERAPAN AKUNTANSI BERBASIS AKRUAL PADA PEMERINTAHAN DAERAH KALIMANTAN BARAT
}

\author{
Endang Kristiawati \\ Universitas Panca Bhakti Pontianak
}

\begin{abstract}
This study aims to determine what factors are instrumental in the successful implementation of accrual based accounting in the Environment Government of West Kalimantan Province. This type of research is case study based on the model Luder (1992), using a qualitative approach. Study sites in West Kalimantan regional administration, sample's in this study are SKPD-SKPD in regional government of West Kalimantan Province. Data collection techniques using observation, indepth interview, and documentation. Data analysis using data reduction, presentation of data and drawing conclusions / verification., the technique checks the validity of the data using the method of triangulation. The analysis of this study suggest that in general local government officials in West Kalimantan environment to understand what was essentially based on accrual accounting system, although not yet fully understood. From the findings and analysis of data, there are several factors that are most instrumental in the successful implementation of accrual accounting in government of West Kalimantan, namely commitment, quality human resources required, and Tool Support.
\end{abstract}

Keywords: Accrual Basis, Cash Toward Accrual, Commitment, Human Resources

ABSTRAK: Penelitian ini bertujuan untuk mengetahui faktor-faktor apa yang berperan dalam keberhasilan pelaksanaan akuntansi berbasis akrual di Lingkungan Pemerintah Provinsi Kalimantan Barat. Jenis penelitian ini adalah studi kasus berdasarkan model Luder (1992), dengan menggunakan pendekatan kualitatif. Lokasi penelitian di pemerintahan daerah Kalimantan Barat, sampel dalam penelitian ini adalah SKPD-SKPD di pemerintah daerah Provinsi Kalimantan Barat. Teknik pengumpulan data menggunakan observasi, wawancara mendalam, dan dokumentasi. Analisis data menggunakan reduksi data, penyajian data dan penarikan kesimpulan / verifikasi. Teknik memeriksa validitas data menggunakan metode triangulasi. Analisis penelitian ini menunjukkan bahwa dalam pejabat pemerintah daerah umum di lingkungan Kalimantan Barat untuk memahami apa yang pada dasarnya berdasarkan sistem akuntansi akrual, meski belum sepenuhnya dipahami. Dari temuan dan analisis data, ada beberapa faktor yang paling berperan dalam keberhasilan pelaksanaan akuntansi akrual di pemerintah Kalimantan Barat, yaitu komitmen, sumber daya manusia yang berkualitas diperlukan, dan Alat Dukungan.

Kata Kunci: Basis Akrual, Kas Menuju Akrual, Komitmen, Sumber Daya Manusia

\footnotetext{
${ }^{1}$ Draft pertama: 03 Sepetember 2015; Revisi: 12 Oktober 2015; Diterima: 09 November 2015 Penulis dapat dikontak melalui: endangkristiawati@yahoo.co.id
} 


\section{PENDAHULUAN}

Pada tahun 1980-an reformasi sektor publik dilakukan di Negara-negara industri maju sebagai jawaban atas berbagai kritikan. Berbagai perubahan dilakukan misalnya dengan mengadopsi pendekatan New Public Management (NPM) dan reinventing goverment dibanyak negara terutama Negara Anglo Saxon. New Public Management merupakan fenomena global yang mempunyai tujuan untuk memperbaiki efisiensi dan efektivitas, meningkatkan responsifitas dan memperbaiki akuntabilitas manajerial organisasi publik (Bambang Sancoko, dkk, 2008).

Penerapan New Public Management di Indonesia diawali dengan adanya reformasi di bidang keuangan dengan lahirnya tiga paket undang-undang, yaitu Undang-Undang No. 17 Tahun 2003 tentang Keuangan Negara, Undang-Undang No. 1 tahun 2004 tentang Perbendaaraan Negara, dan Undang-undang No. 15 tahun 2004 tentang Pemeriksaan Pengelolaan dan Tanggungjawab Keuangan Negara, telah menandai dimulainya era baru dalam pengelolaan keuangan negara (Akhmad Solikin, 2006). Dari fenomena tersebut maka lahir PP No 24 tahun 2005 tentang Standar Akuntansi Pemerintahan berbasis Cash Toward Accrual yang kemudian diikuti dengan lahirnya PP No. 71 Tahun 2010 tentang Standar Akuntansi Pemerintahan Berbasis Akrual. Dimana ini merupakan suatu keinginan dari berbagai pihak untuk dapat menciptakan suatu pengelolaan keuangan publik yang lebih transparansi dan dapat memperbaiki efisiensi dan efektivitas publik.

Sebagai wujud dari suatu bentuk reformasi maka Pemerintah Indonesia telah mencanangkan untuk melakukan perubahan reformasi terutama di bidang akuntansi. Salah satu reformasi yang dilakukan oleh Pemerintah adalah keharusan untuk menerapkan akuntansi berbasis akrual pada setiap instansi pemerintahan, baik pemerintah pusat maupun pemerintahan daerah, yang dimulai tahun anggaran 2008. Hal ini ditegaskan dalam Undang-Undang Nomor 17 Tahun 2003 tentang Keuangan Negara dalam Pasal 36 ayat (1) yang berbunyi sebagai berikut:

"Ketentuan mengenai pengakuan dan pengukuran pendapatan dan belanja berbasis akrual sebagaimana dimaksud dalam Pasal 1 angka 13, 14, 15, dan 16 undang-undang ini dilaksanakan selambat-lambatnya dalam 5 (lima) tahun. Selama pengakuan dan pengukuran pendapatan dan belanja berbasis akrual belum dilaksanakan, digunakan pengakuan dan pengukuran berbasis kas."

Berdasarkan pada penelitian terdahulu Harun El-Raseed dan Peter Robinson, 2005 mengenai perubahan reformasi akuntansi sektor publik di Indonesia dengan mengadopsi akuntansi akrual sebagai dasar bagi manajemen sektor publik dan pelaporan keuangan di Indonesia dengan mengembangkan model kontingensi inovasi akuntansi pemerintahan yang dikembangkan oleh Luder (1992). Maka penelitian ini bermaksud untuk mengembangkan pembahasan mengenai faktor-faktor yang mempengaruhi keberhasilan penerapan akuntansi berbasis akrual dengan mengadaptasi model inovasi akuntansi pemerintahan yang dikembangkan oleh Luder (1992) dalam persepsi pegawai publik selaku pelaksana dari sistem akuntansi berbasis akrual.

Fokus pertanyaan didalam penelitian ini adalah (1) Faktor-faktor apa saja yang berperan penting dalam keberhasilan penerapan akuntansi berbasis akrual di Lingkungan Pemerintahan Daerah Provinsi Kalimantan Barat. (2) Bagaimana pendapat dan persepsi mengenai pemahaman pegawai publik pada pemerintahan daerah Provinsi Kalimantan Barat tentang sistem akuntansi berbasis akrual.

\section{KERANGKA TEORI DAN PENGEMBANGAN HIPOTESIS}

\section{New Public Management (NPM)}

New Public Management (NPM) merupakan sistem manajemen administrasi publik yang paling aktual di seluruh dunia dan sedang direalisasikan di hampir seluruh negara 
industri. New Public Management tidak selalu dipahami sama oleh semua orang. Bagi sementara orang, NPM adalah suatu sistem manajemen desentral dengan perangkatperangkat manajemen baru seperti controlling, benchmarking dan lean management; bagi yang lain, NPM dipahami sebagai privatisasi sejauh mungkin atas aktivitas pemerintah.

Tujuan New Public Management adalah untuk merubah administrasi publik sedemikian rupa sehingga, kalaupun belum bisa menjadi perusahaan, ia bisa lebih bersifat seperti perusahaan. Administrasi publik sebagai penyedia jasa bagi warga harus sadar akan tugasnya untuk menghasilkan layanan yang efisien dan efektif. Tapi, di lain pihak ia tidak boleh berorientasi pada laba. Sedangkan menurut Osborne dan Gaebler (1995), tujuan dari New Public Management adalah untuk mengubah administrasi yang sedemikian rupa sehingga administrasi publik sebagai penyedia jasa bagi masyarakat harus sadar akan tugasnya untuk menghasilkan layanan yang efisien dan efektif, namun tidak berorientasi kepada laba.

\section{Teori Kontigensi}

Menurut Etzzioni (1985) dalam buku yang berjudul "Modern Organization" menyatakan bahwa teori kontigensi Disebut juga teori kepentingan, teori lingkungan atasi teori situasi. Teori Kotingensi berlandaskan pada suatu pemikiran bahwa pengelolaan organisasi dapat berjalan dengan baik dan lancar apabila pemimpin organisasi mampu memperhatikan dan memecahkan situasi tertentu yang sedang dihadapi dan setiap situasi harus dianalisis sendiri. Menurut Stoner et al., (1996:47) pendekatan kontigensi atau pendekatan situasional merupakan suatu "pandangan bahwa teknik manajemen yang paling baik memberikan kontribusi untuk pencapaian sasaran organisasi mungkin bervariasi dalam situasi atau lingkungan yang berbeda.

Munculnya teori kontijensi dalam akuntansi pemerintahan berawal dari adanya keinginan untuk melakukan suatu reformasi terhadap sistem akuntansi pemerintahan dari sistem akuntansi tradisional menjadi sistem akuntansi yang lebih informatif. Sistem yang lebih informatif akan tertuju pada pasokan informasi yang komprehensif dan dapat diandalkan serta menyediakan dasar untuk kontrol keuangan pada kegiatan pemerintah.

\section{Model Akuntansi Inovasi}

Model yang digunakan dalam penelitian ini adalah model kontingensi untuk inovasi akuntansi pemerintahan yang dikembangkan oleh Luder (1992). Menurut model ini, ada empat variabel kontekstual dalam menjelaskan hasil dari inovasi akuntansi; (1) rangsangan (2) lingkungan sosial pemerintah, (3) karakteristik dari sistem administrasi politik dan (4) hambatan implementasi (Monsen et al 1998). hipotesis dari tiga model pertama jenis variabel kontekstual positif akan mempengaruhi sikap dan perilaku pengguna dan produsen informasi keuangan pemerintah. Namun, untuk model yang keempat, hambatan implementasi mencegah hasil yang sukses dalam pelaksanaan inovasi apapun dalam proses akuntansi pemerintahan.

Model ini mengusulkan bahwa adanya masa transisi dari akuntansi tradisional menuju ke sistem akuntansi pemerintah yang lebih informatif. Sistem yang lebih informatif akan tertuju pada pasokan informasi yang komprehensif dan dapat diandalkan serta menyediakan dasar untuk kontrol keuangan pada kegiatan pemerintah. Model ini juga menjelaskan proses inovasi yang menghubungkan dua titik, dimana tingkat kompleksitas yang cukup tinggi sehingga tidak mungkin dapat diuji secara statistik. Untuk lebih jelasnya berikut model luder (1992) mengenai model kontigensi inovasi akuntansi sektor publik model dasar: 


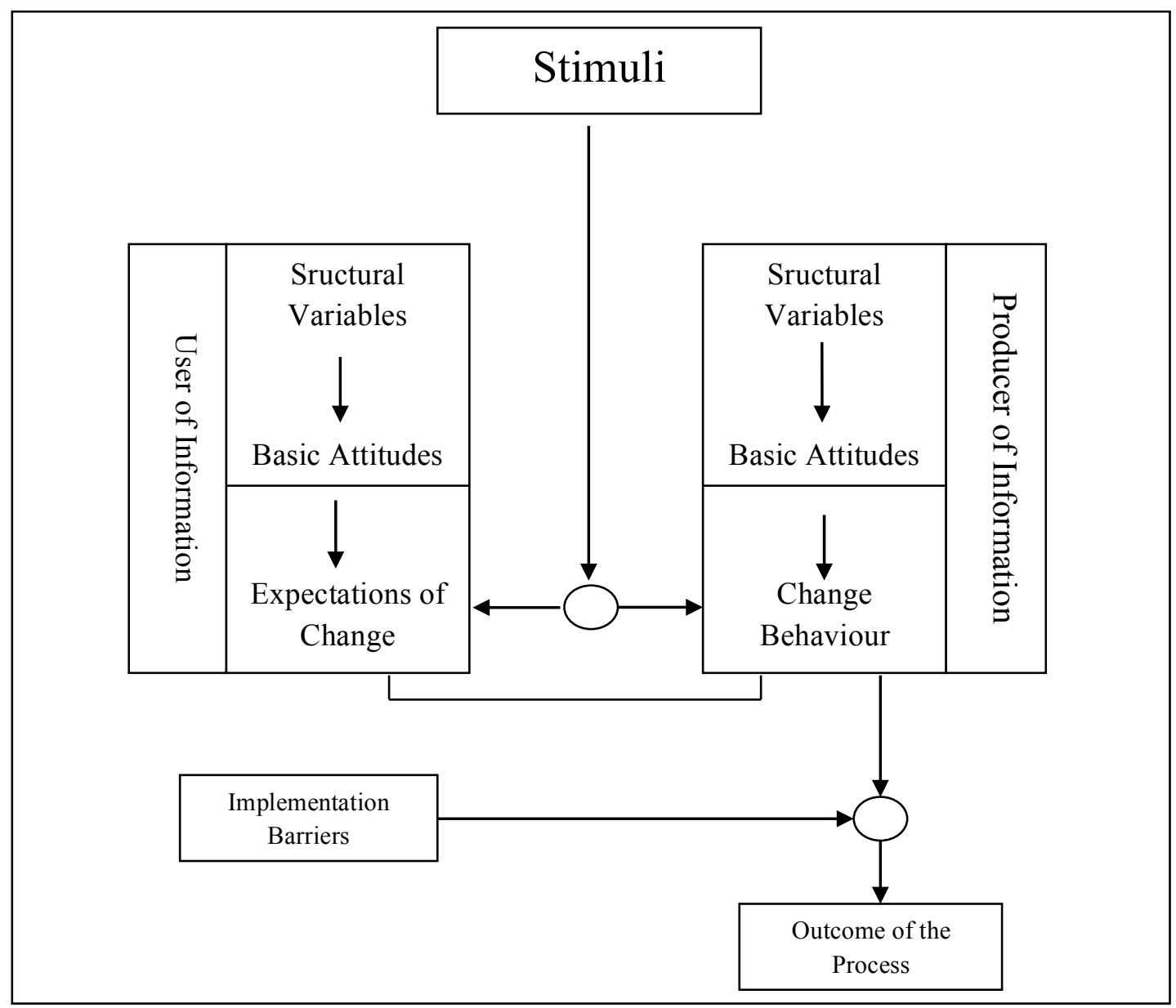

Gambar 2.1. Model kontijensi inovasi akuntansi sektor publik-model dasar

\section{Proses Basis kas ke Basis Akrual}

Menurut study 14 IFAC, sifat dan kecepatan dari penerapan basis akrual tergantung pada sejumlah faktor. Isu-isu pada masa transisi menuju implementasi basis akrual harus diidentifikasi secara komprehensif dan dikaji secara mendalam, sebab perubahan tersebut tentunya bukan sekedar perubahan teknis akuntansi akan tetapi mempengaruhi sejumlah faktor lainnya yang harus dipersiapkan terlebih dahulu. Dengan demikian beberapa isu-isu dalam transisi menuju akrual yang diantaranya:

a. Apakah penggunaan basis akrual hanya untuk pelaporan keuangan saja atau akan diterapkan juga dalam reformasi yang lebih luas, misalnya dalam penganggaran.

b. Apakah penerapan basis akrual akan dilakukan secara top-down atau bottom-up. Bila diterapkan secara top-down biasanya penerapan basis akrual dilakukan secara mandatory (wajib) untuk semua entitas dalam rentang waktu (time frame) yang pasti dan seragam. Sedangkan bila diterapkan secara bottom-up, harus dilakukan pilot project terlebih dahulu pada entitas tertentu, untuk meyakinkan bahwa basis akrual dapat dilaksanakan dengan baik.

c. Komitmen di level politik untuk menerapkan akuntansi akrual

d. Kapasitas dan keahlian orang - orang yang terkait dan/atau bertanggungjawab dengan adanya perubahan tersebut.

e. Peraturan perundang - perundangan yang terkait dengan pengelolaan keuangan negara yang ada.

f. Standar akuntansi yang sedang berjalan dan persiapan perubahannya. 
g. Kelengkapan dan keakuratan informasi keuangan yang ada, terutama informasi tentang aset dan kewajiban (utang).

\section{Akuntansi Berbasis Akrual}

Teori akuntansi basis akrual menurut Kohler's Dictionary for Accountansts 6th Ed. (1983) dalam chairul iman (2008) adalah :

"the method of accounting whereby revenues and expenses are identified with specific periods of time, such as a month or year, and are recorded as incurred, along with acquired assets, without regard to the date of receipt or payment of cash."

Sedangkan menurut Standar Akuntansi Pemerintah (SAP) adalah: "...suatu basis akuntansi dimana transaksi ekonomi dan peristiwa lainnya diakui, dan disajikan dalam laporan keuangan pada saat terjadinya transaksi tersebut, tanpa memperhatikan waktu kas atau setara kas diterima atau dibayarkan.”

\section{Tantangan Akuntansi Berbasis Akrual}

Ada beberapa tantangan dalam implementasi akuntansi pemerintahan berbasis akrual yang diantaranya adalah (Binsar, 2010):

1. Sistem akuntansi dan IT Based System;

2. Komitmen dari pimpinan;

3. Tersedianya SDM yang kompeten

4. Resistensi terhadap perubahan

\section{METODE PENELITIAN}

\section{Jenis Penelitian}

Jenis penelitian ini adalah studi kasus yang didasarkan pada model Luder (1992), dimana model kontingensi ini menyarankan bahwa kemungkinan keberhasilan penerapan akuntansi berbasis akrual tergantung pada beberapa faktor yang diantaranya adalah : (a) Rangsangan untuk reformasi, (b) Struktural variabel yang terdiri dari pengguna dan produsen informasi akuntansi, dan (c) Signifikansi hambatan implementasi.

Penelitian menggunakan pendekatan kualitatif dimana maksud dari penelitian kualitatif adalah untuk memahami fenomena tentang apa yang dialami oleh subjek penelitian, misalnya perilaku, persepsi, motivasi, tindakan dan lain-lain secara holistik dengan cara deskripsi dalam bentuk kata-kata dan bahasa pada suatu konteks khusus yang alamiah dan dengan memanfaatkan berbagai metode yang alamiah (Moleong, 2010).

\section{Populasi dan Sampel}

Populasi dalam penelitian ini adalah SKPD-SKPD yang ada di lingkungan pemerintah daerah Provinsi Kalimantan Barat. Sampel yang dipilih adalah kota pontianak, provinsi kalimantan barat dan kabupaten sanggau. Strategi pengambilan sampel yang digunakan dalam penelitian ini dikenal sebagai sampling tujuan (patton, 1990).

\section{Teknik Pengumpulan Data}

Metode penelitian yang digunakan dalam penelitian ini adalah metode kualitatif. Metode kualitatif yang digunakan menghasilkan data deskriptif, ucapan atau tulisan dan perilaku yang dapat diamati dari orang-orang atau subjek itu sendiri. Dengan demikian peneliti menggunakan metode: observasi, indepth interview dan dokumentasi.

\section{Teknik Analisis Data}

Teknis analisis data yang digunakan dalam penelitian ini adalah deskriptif naratif. Teknis analisis data ini menggunakan model Miles dan Huberm 


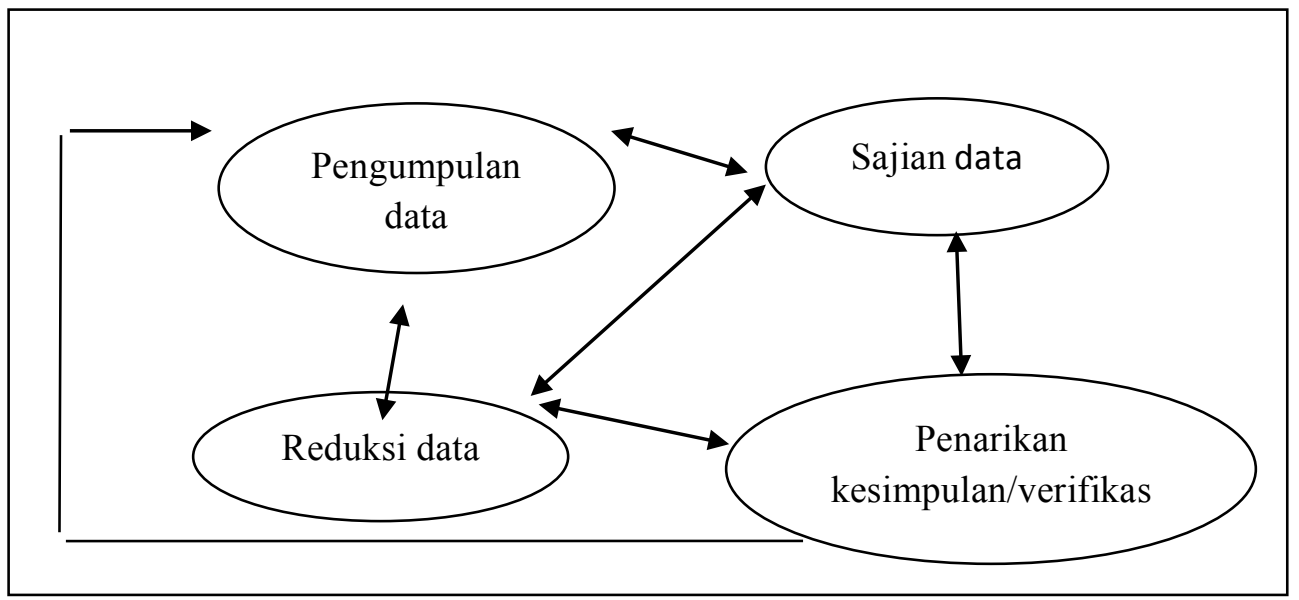

Gambar 3.1 Analisis data Kualitatif Model Miles \& Huberman

\section{Keabsahan Data}

Untuk menetapkan keabsahan data diperlukan teknik pemeriksaan, salah satu kriteria keabsahan data yang digunakan penulis adalah kepercayaan (credibility) dengan teknik pemeriksaan menggunakan metode triagulasi. Teknik triangulasi yang dilakukan untuk pemeriksaan validitas / keabsahan data, meliputi:

1. Triangulasi sumber

2. Triangulasi metode

3. Triagulasi Data

\section{HASIL DAN PEMBAHASAN}

\section{Hasil Penelitian}

Dalam Rangka implementasi PP No. 71 Tahun 2010 tentang Standar Akuntansi Pemerintahan Berbasis Akrual yang akan dilaksanakan pada tahun 2015, maka setiap pemerintah daerah harus dapat mempersiapkan diri untuk merealisasikan sistem akuntansi dalam penyusunaan laporan keuangan pemerintahan daerah sesuai dengan peraturan yang berlaku. Sistem akuntansi adalah prosedur - prosedur yang harus dilaksanakan untuk menghasilkan informasi yang dibutuhkan oleh pihak - pihak di dalam dan di luar organisasi. Sedangkan basis akuntansi merupakan suatu prinsip - prinsip akuntansi yang menentukan kapan pengaruh atas transaksi atau kejadian harus diakui untuk tujuan pelaporan keuangan (Pramono Dkk 2010).

Dalam menunjang keberhasilan penerapan akuntansi berbasis akrual, maka sudah seharusnya pemerintah daerah harus dapat melakukan pembenahan diri baik dalam hal SDM maupun hal - hal lainnya yang berkaitan dengan kesiapan dan keberhasilan penerapan akuntansi berbasis akrual. Berdasarkan uraian latar belakang dan metodologi penelitian pada bab-bab sebelumnya, dan untuk melihat sejauh mana kesiapan pegawai publik serta pemahaman mereka terhadap akuntansi akrual yang pelaksanaannya dilaksanakan pada tahun 2014. Dalam penelitian ini penulis melakukan pendekatan kualitatif dengan melakukan wawancara langsung dengan informan yang dipilih. Informan yang dipilih adalah para pelaksana akuntansi pemerintahan yaitu pegawai publik yang merupakan pimpinan dan staf akuntansi.

Dari hasil data wawancara yang telah dikumpulkan dan diikuti dengan data dokumentasi berupa kebijakan akuntansi pemerintahan daerah serta melakukan observasi langsung, maka hasil dari sajian data berupa wawancara dilakukan pemahaman untuk menentukan tema dari wawancara yang juga merupakan faktor-faktor yang mempengaruhi keberhasilan 
penerapan akuntansi berbasis akrual pada Pemerintahan Daerah Kalimantan Barat dan juga merupakan suatu hambatan dalam implementasi akuntansi akrual nantinya. Berikut ini disajikan tabulasi dari hasil wawancara dapat dilihat pada tabel 4.1 berikut ini:

Tabel 4.1 Analisis data Hasil Wawancara

\begin{tabular}{|c|c|c|c|}
\hline \multicolumn{3}{|c|}{ Triangulasi } & \multirow{2}{*}{$\begin{array}{l}\text { Tema } \\
\text { Wawancara }\end{array}$} \\
\hline $\begin{array}{l}\text { Informasi dari hasil } \\
\text { wawancara }\end{array}$ & $\begin{array}{r}\text { Kode } \\
\text { Wawancara }\end{array}$ & $\begin{array}{l}\text { Data } \\
\text { Lainnya }\end{array}$ & \\
\hline $\begin{array}{l}\text { Sudah dilakukan MOU } \\
\text { dengan BPKP dan Bawasda }\end{array}$ & IR\#2.A1 & & \\
\hline $\begin{array}{l}\text { Belum ada follow up } \\
\text { dari pusat atas perubahan basis } \\
\text { akuntansi }\end{array}$ & IR\#1.A1 & & $\begin{array}{l}\text { Komit } \\
\text { men Atasan }\end{array}$ \\
\hline $\begin{array}{l}\text { Belum ada sosialisasi } \\
\text { maupun Bimtek atas sistem } \\
\text { akuntansi berbasis akrual }\end{array}$ & IR\#4.A3 & & \\
\hline $\begin{array}{l}\text { Pencatatan double } \\
\text { entry telah dilaksanakan }\end{array}$ & IR\#3.C 1 & \multirow{5}{*}{$\begin{array}{l}\text { Dokume } \\
\text { n Laporan } \\
\text { Keuangan }\end{array}$} & \multirow{5}{*}{$\begin{array}{l}\text { Pemah } \\
\text { aman Sistem } \\
\text { akuntansi } \\
\text { akrual }\end{array}$} \\
\hline $\begin{array}{l}\text { Praktek akrual hanya } \\
\text { sebatas laporan Neraca }\end{array}$ & IR\#6.C2 & & \\
\hline $\begin{array}{c}\text { Belum dilakukan } \\
\text { pengakuan beban penyusutan }\end{array}$ & $\mathrm{IR}_{5} \cdot \mathrm{C}_{7}$ & & \\
\hline $\begin{array}{l}\text { Pengakuan pendapatan } \\
\text { masih berbasis kas }\end{array}$ & IR\#2.C6 & & \\
\hline $\begin{array}{l}\text { Di rasa sulit } \\
\text { menerapkan full akrual } \\
\text { didalam pemerintahan }\end{array}$ & IR\#1.A3 & & \\
\hline $\begin{array}{l}\text { Sering terjadinya } \\
\text { rolling pegawai }\end{array}$ & IR\#2.A3 & \multirow{2}{*}{$\begin{array}{l}\text { Observas } \\
\mathrm{i}\end{array}$} & \multirow{2}{*}{$\begin{array}{l}\text { SDM } \\
\text { dengan } \\
\text { kualifikasi } \\
\text { yang } \\
\text { diperlukan } \\
\end{array}$} \\
\hline $\begin{array}{l}\text { Belum adanya } \\
\text { pelatihan bagi staf akuntansi }\end{array}$ & $\mathrm{IR}_{5} \mathrm{~A}_{3}$ & & \\
\hline $\begin{array}{l}\text { Perlunya perangkat } \\
\text { pendukung lainnya seperti } \\
\text { kebijakan akuntansi }\end{array}$ & IR\#1.A2 & \multirow{2}{*}{$\begin{array}{l}\text { Observas } \\
\mathrm{i}\end{array}$} & \multirow{2}{*}{$\begin{array}{l}\text { Perang } \\
\text { kat } \\
\text { Pendukung }\end{array}$} \\
\hline $\begin{array}{l}\text { Adanya sistem } \\
\text { akuntansi yang } \\
\text { terkomputerisasi }\end{array}$ & IR\#2.C 1 & & \\
\hline
\end{tabular}

Selanjutnya untuk melihat secara rinci mengenai pemahaman dan pengenalan mereka tentang akuntansi akrual yang berupa pendapat dan persepsi dari pimpinan maupun staf akuntansi yang merupakan pelaksana dari sistem akuntansi akrual di lingkungan pemerintahan daerah Kalimantan Barat, maka berikut ini adalah interpretasi atas temuan yang dikaitkan dengan teori yang dapat mendukung serta untuk membandingkan hasil- hasil penelitian sebelumnya, berikut hasil penelitian yang diuraikan secara rinci:

\section{Pemahaman sistem akuntansi berbasis akrual}

Akuntansi berbasis akrual berarti suatu basis akuntansi di mana transaksi ekonomi dan peristiwa-peristiwa lain diakui dan dicatat dalam catatan akuntansi dan dilaporkan 
dalam periode laporan keuangan pada saat terjadinya transaksi tersebut, bukan pada saat kas atau ekuivalen kas diterima atau dibayarkan. Akuntansi berbasis akrual ini banyak dipakai oleh institusi sektor non publik dan lembaga lain yang bertujuan mencari keuntungan. International Monetary Fund (IMF) sebagai lembaga kreditur menyusun Government Finance Statistics (GFS) yang di dalamnya menyarankan kepada negara-negara debiturnya untuk menerapkan akuntansi berbasis akrual dalam pembuatan laporan keuangan.

Alasan penerapan basis akrual ini karena saat pencatatan (recording) sesuai dengan saat terjadinya arus sumber daya. Jadi basis akrual ini menyediakan estimasi yang tepat atas pengaruh kebijakan pemerintah terhadap perekonomian secara makro. Selain itu basis akrual menyediakan informasi yang paling komprehensif karena seluruh arus sumber daya dicatat, termasuk transaksi internal, in-kind transaction, dan arus ekonomi lainnya. Dari penjelasan diatas maka secara umum pegawai publik sudah mengerti mengenai maksud dan makna dari sistem akuntansi berbasis akrual. Ini terbukti dari hasil wawancara dengan pimpinan dan staf akuntansi di pemerintahan daerah Kalimantan Barat. Seperti halnya IR\#1 Prov Kalbar yang mengatakan:

"setiap transaksi diakui dan dicatat tanpa memperhatikan kas masuk atau keluar.."

Hal senada juga disampaikan pada tingkat staf yang juga telah memahami maksud dari akuntansi akrual walaupun hanya garis besarnya saja. Seperti hasil wawancara dengan IR\# 5 Prov. Kalbar, yang mengatakan:

"setahu saya basis akrual adalah setiap transaksi yang terjadi diakui dan dicatat tanpa melihat penerimaan maupun pengeluaran kas"

Dari hasil pendapat pegawai publik mengenai basis akrual telah sesuai dengan definisi akuntansi akrual itu sendiri, sehingga dengan kata lain para pegawai publik sudah mengerti apa itu basis akrual, walaupun belum sepenuhnya.

\section{Lingkungan/kondisi yang berorientasi pada penerapan akuntansi akrual}

Meskipun pada dasarnya pegawai telah mengetahui maksud dari akuntansi akrual, tapi pada kenyataanya penerapan akuntansi berbasis akrual masih dipandang sulit untuk diterapkan, ini dapat dilihat dari hasil wawancara mengenai kondisi/lingkungan yang berorientasi pada penerapan akuntansi akrual, yaitu sebagai berikut:

a. Kondisi instansi yang ada dalam mendukung penerapan akuntansi akrual

Keberhasilan penerapan akuntansi berbasis akrual di pemerintahan daerah sangat tergantung dari dukungan instansi itu sendiri serta komitmen yang kuat dari atasan untuk melakukan suatu perubahan. Dengan kata lain kondisi lingkungan akan sangat berpengaruh seperti hasil wawancara berikut ini, IR\#1 Prov. Kalbar mengatakan:

"Mendukung mbak, tetapi selain itu kita juga harus ada dukungan dari pusat mengenai bimtek untuk PP 71 itu sendiri karena sampai saat ini belum ada,...." Hal yang sama juga disampaikan oleh IR\#2 Kota Pontianak yang mengatakan:

“.....untuk dukungan dari instansi kita, ini sudah dilakukan diawal 2012 yaitu sudah ada MOU dengan BPKP untuk koordinasi begitu juga dengan BPK, dan Insyaallah ditahun ini kita juga akan memyempurnakan kebijakan akuntansi kita untuk mengacu ke akrual secara bertahap serta sistem dan prosedur pengelolaan keuangan pemerintah kota....."

Dilihat dari fenomena diatas maka lingkungan instansi yang mendukung penerapan akuntansi akrual masih sangat kurang. Sehingga disetiap daerah harus mempunyai trik tersendiri dalam penerapan akuntansi akrual. Hal ini sangat bertentangan dengan Undang-undang nomor 17 tahun 2003 tentang keuangan negara, dimana setiap 
instansi pemerintahan baik pusat maupun daerah sudah harus memulai melakukan pengakuan dan pengukuran akuntansi dengan menggunakan sistem akuntansi akrual. Begitu juga dengan PP No. 24 tahun 2005 mengenai Standar Akuntansi Pemerintahan berbasis Cash Toward Accrual (CTA) yang sudah diarahkan pada sistem akuntansi kas menuju akrual. Dengan demikian, sudah seharusnya setiap instansi pemerintahan khususnya lingkungan organisasi pemerintah daerah Kalimantan Barat memulai penerapan akuntansi akrual dari sekarang dengan menyiapkan sumber daya manusia serta perangkat pendukung.

b. Sikap atasan terhadap penerapan akuntansi akrual

Suatu perubahan dari reformasi sistem akuntansi sektor publik sangat dipengaruhi oleh komitmen dari atasan. Dimana dukungan yang kuat dari pimpinan merupakan kunci keberhasilan dari suatu perubahan. Salah satu penyebab lemahnya reformasi dari sistem akuntansi sektor publik, karena masih lemahnya komitmen pimpinan satuan kerja khususnya SKPD dalam memberikan dukungannya. Dengan masih lemahnya komitmen dari atasan untuk penerapan akuntansi akrual terutama di setiap SKPD - SKPD ini seperti yang diungkapkan oleh IR\#4 Kota Pontianak yang mengatakan:

"Kalau untuk atasan sendiri saat ini belum terfokus ke situ ya mbak, tapi saya yakin ketika sudah harus menerapkan basis akrual atasan pasti mendukung dan akan menyiapkan segalanya. Jadi menurut saya bentuk dukungan saat ini yang diperlukan adalah dengan menyiapkan SDM yang berkualitas serta segera untuk memberikan sosialisasi di setiap dinas-dinas...”

Begitu juga hal nya yang disampaikan oleh IR\#5 Prov. Kal-Bar yang mengatakan :

"Mengenai sikap atasan sebenarnya mendukung, tetapi yang kami dapat hanya sebatas informasi saja mengenai pelaksanaan teknis yaitu pelaksanaan yang dimulai pada tahun 2014. Sehingga sikap atasan secara nyata belum, untuk saat ini...."

Berbeda dengan yang diutarakan oleh IR\#6 Dinas kesehatan kab. Sanggau, yang mengatakan:

"Atasan sangat mendukung, walaupun saat ini masih dalam bentuk kerjasama dan MOU dengan BPKP, ya... dengan tujuan supaya kita bisa belajar lebih banyaklah mengenai basis akrual ini."

Jika dilihat dari komitmen atasan di setiap Dinas hanya sebatas mendukung untuk penerapan akuntansi akrual ini. tetapi bentuk nyata dari dukungan tersebut belum diberikan sepenuhnya hanya sebatas MOU dengan BPKP. Dari fenomena diatas maka ini akan sangat bertentangan dengan teori komitmen itu sendiri, dimana menurut Meyer et al (dalam elya dkk, 2010) komitmen adalah derajat sejauh mana keterlibatan seseorang dalam organisasinya dan kekuatan identifikasinya terhadap suatu organisasi tertentu. Karenanya komitmen organisasi ditandai dengan tiga hal yang diantaranya adalah:

a. Suatu kepercayaan yang kuat terhadap organisasi dan penerimaan terhadap tujuantujuan dan nilai-nilai organisasi.

b. Keinginan yang kuat untuk memelihara hubungan yang kuat dengan organisasi, dan

c. Kesiapan dan kesediaan untuk meyerahkan usaha keras demi kepentingan organisasi.

Sehingga ini dapat disimpulkan bahwa jika tidak ada komitmen yang kuat dari atasan maka akan terasa sulit dalam suatu proses perubahan dalam hal ini adalah penerapan sistem akuntansi akrual. Karena disetiap daerah akan dituntut kesiapan dan kesediaan mereka untuk melakukan perubahan dengan melakukan trik tersendiri serta 
mendesain sendiri sistem akuntansi yang dituangkan dalam bentuk kebijakan akuntansi pemerintahan daerah. ini akan sangat sesuai dengan teori kontijensi yang diungkapkan oleh Etzzioni (1985) bahwa pengelolaan organisasi dapat berjalan baik dan lancar apabila pemimpin organisasi mampu memperhatikan dan memecahkan situasi tertentu yang sedang dihadapi dan setiap situasi harus dianalisis sendiri.

\section{Tujuan Laporan Keuangan sebagai pengawasan}

Berdasarkan SAP berbasis Akrual, laporan keuangan merupakan laporan yang terstruktur mengenai posisi keuangan dan transaksi-transaksi yang dilakukan oleh suatu entitas pelaporan. Tujuan umum laporan keuangan adalah menyajikan informasi mengenai posisi keuangan, realisasi anggaran, saldo anggaran lebih, arus kas, hasil operasi, dan perubahan ekuitas suatu entitas pelaporan yang bermanfaat bagi para pengguna dalam membuat dan mengevaluasi keputusan mengenai alokasi sumber daya.

Laporan keuangan untuk tujuan umum juga mempunyai peranan prediktif dan prospektif, menyediakan informasi yang berguna untuk memprediksi besarnya sumber daya yang dibutuhkan untuk operasi yang berkelanjutan, sumberdaya yang dihasilkan dari operasi yang berkelanjutan, serta risiko dan ketidakpastian yang terkait. Dalam hal tujuan laporan keuangan seperti yang dinyatakan dalam Standar Akuntansi Pemerintahan Berbasis Akrual, maka sistem akuntansi akrual dirancang untuk dapat menfasilitasi pengawasan baik itu anggaran, para legislatif maupun masyarakat umum, hal ini senada seperti yang disampaikan oleh IR\#1, Prov. Kal Bar yang mengatakan :

"Saya rasa setiap sistem nantinya sudah harus dapat mengawasi karena itukan tujuan dari laporan keuangan iya kan tetap harus dapat mengawasi anggaran dan penggunaannya."

Begitu juga halnya dengan IR\#2 Kota Pontianak yang mengatakan :

"Menurut saya, mungkin kedepannya harus bisa, kan basis akrual sudah di mulai dari anggaran...."

Dan ketika ditanyakan bagaimana untuk pemantauan masyarakat umum maka IR\#2 kota pontianak mengatakan :

"Kalau untuk hal ini saya rasa jauh bisa lebih di kontrol karena setiap aktivitas sudah kelihatan dan setiap pendapatan sudah diakui terlebih dahulu begitu juga dengan penggunaannya....."

Menyimak fenomena diatas maka dapat disimpulkan bahwa sistem akuntansi berbasis akrual jauh lebih bisa di pantau oleh para pengguna dan masyarakat umum, Selain itu dengan sistem akuntansi akrual ini anggaran juga dapat diawasi karena dengan mengacu pada akuntansi akrual nantinya akan di mulai dari penyusunan anggaran sehingga semua sumber daya ekonomi dan aktivitas pemerintah dapat dikontrol secara jelas bagi para pengguna laporan keuangan pemerintahan daerah. ini sesuai dengan tujuan dari laporan keuangan yang tercantum pada Peraturan Pemerintah Nomor 24 tahun 2005 dan Peraturan Pemerintah Nomor 71 Tahun 2010 tentang SAP.

\section{Sistem pengakuan dan pengukuran akuntansi berbasis akrual}

Selanjutnya untuk melihat sejauh mana pemahaman para pegawai publik dibidang akuntansi mengenai teknis dari sistem akuntansi berbasis akrual maka hasil wawancara berikut ini mengenai pemahaman sistem pengakuan dan pengukuran akuntansi berbasis akrual yang ditanyakan pada kasubag dan staf akuntansi di SKPD - SKPD. Berikut hasil wawancara yang telah di tabulasi dari tiga SKPD yang berbeda : 
Tabel 4.2 Hasil Wawancara Sistem Pengakuan dan Pengukuran Akuntansi Berbasis Akrual

\begin{tabular}{|c|c|c|c|}
\hline \multirow{2}{*}{ Pertanyaan } & \multicolumn{3}{|c|}{ Hasil Jawaban Responden } \\
\hline & IR\#4 & IR\# 5 & IR\#6 \\
\hline \begin{tabular}{l}
\multicolumn{2}{c}{ Apakah } \\
sistem \\
pembukuan \\
double entry \\
masih digunakan?
\end{tabular} & $\begin{array}{l}\text { Untuk double } \\
\text { entry, yang debet } \\
\text { sama kredit itu ya.. } \\
\text { itu sih sudah dan saat } \\
\text { ini masih digunakan. }\end{array}$ & $\begin{array}{l}\text { Iya kita sudah } \\
\text { menggunakan double } \\
\text { entry, maksudnya } \\
\text { yang setiap } \\
\text { pencatatan didebet } \\
\text { selalu di ikuti dengan } \\
\text { pencatatan di sisi } \\
\text { kredit itu kan... }\end{array}$ & \begin{tabular}{l}
\multicolumn{2}{c}{ Untuk } \\
double \\
sudah bu...
\end{tabular} \\
\hline \begin{tabular}{lr}
\multicolumn{2}{c}{ Apakah } \\
dasar & akrual \\
akuntansi & telah \\
dipraktekkan?
\end{tabular} & $\begin{array}{l}\text { Untuk akrual } \\
\text { hanya pada neraca } \\
\text { saja yang lain belum. }\end{array}$ & $\begin{array}{l}\text { Akrual sudah } \\
\text { tapi hanya pada } \\
\text { laporan neraca saja. }\end{array}$ & \begin{tabular}{lr}
\multicolumn{2}{c}{ Pada } \\
dasarnya sudah \\
tapi hanya untuk \\
neraca & saja, yaitu \\
aset, kewajiban \\
dan ekuitas nya... \\
yang lainnya \\
belum masih \\
basis kas
\end{tabular} \\
\hline \begin{tabular}{l}
\multicolumn{2}{c}{ Apakah } \\
aset \\
pemerintah telah \\
diakui?
\end{tabular} & $\begin{array}{l}\text { Untuk } \\
\text { pengakuan aset } \\
\text { modal sudah, dan } \\
\text { inventarisasi asetpun } \\
\text { sudah dilakukan } \\
\text { tetapi saya belum } \\
\text { mengethui apakah itu } \\
\text { sudah berbasis akrual } \\
\text { atau belum. }\end{array}$ & 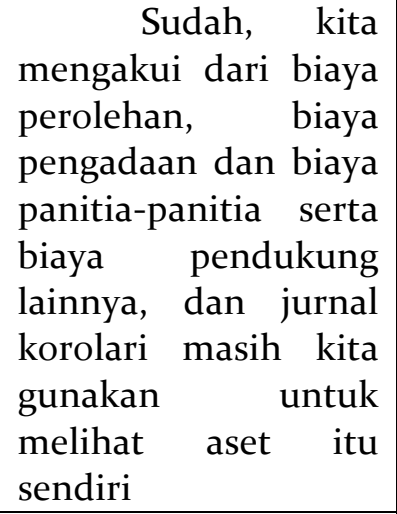 & $\begin{array}{l}\text { aset modal } \\
\text { sudah kita akui } \\
\text { berdasarkan } \\
\text { akrual dan telah } \\
\text { dilakukan } \\
\text { inventarisasi juga } \\
\text { di bagian asetnya } \\
\text { sendiri...seperti } \\
\text { itu bu }\end{array}$ \\
\hline \begin{tabular}{l}
\multicolumn{1}{c}{ Apakah } \\
perhitungan \\
defisit tahunan \\
sudah berdasarkan \\
sistem akrual?
\end{tabular} & \begin{tabular}{l}
\multicolumn{2}{c}{ Kita } \\
melihatnya hanya di \\
laporan Realisasi \\
Anggaran aja mbak...
\end{tabular} & $\begin{array}{lrr} & \text { Saya } & \text { belum } \\
\text { tahu } & \text { mbak... } & \text { surplus } \\
\text { atau defisit } & \text { dilihat } \\
\text { dari LRA aja... } & \end{array}$ & \begin{tabular}{l}
\multicolumn{2}{c}{ Untuk } \\
defisit/surplus \\
kita \\
melihat hanya \\
laporan realisasi \\
anggarannya saja \\
bu
\end{tabular} \\
\hline $\begin{array}{l}\text { Apakah } \\
\text { pengakuan } \\
\text { pendapatan } \\
\text { berdasarkan } \\
\text { penerimaan kas? }\end{array}$ & \begin{tabular}{lr}
\multicolumn{2}{c}{ lya, untuk } \\
sampai saat ini \\
pendapatan masih \\
diakui berdasarkan \\
kas
\end{tabular} & Saat ini iya... & \begin{tabular}{l}
\multicolumn{1}{c}{ Iya, } \\
pendapatan \\
masih \\
berdasarkan \\
penerimaan kas
\end{tabular} \\
\hline $\begin{array}{l}\text { Apakah } \\
\text { beban penyusutan } \\
\text { telah diakui? }\end{array}$ & \begin{tabular}{l}
\multicolumn{2}{c}{ Nah itu masih } \\
jadi problem mbak... \\
memang sampai saai \\
ini kita belum \\
melakukan \\
perhitungan
\end{tabular} & $\begin{array}{lr} & \text { Belum.... } \\
& \text { Karena aturan } \\
\text { dari } & \text { Pergub belum } \\
\text { ada, dan kita di SKPD } \\
\text { kan } \quad \text { mengikuti } \\
\text { Pergub yang ada }\end{array}$ & $\begin{array}{l}\text { iya, untuk } \\
\text { beban } \\
\text { penyusutan kita } \\
\text { sudah mengakui } \\
\text { bu }\end{array}$ \\
\hline
\end{tabular}




\begin{tabular}{|l|l|l|l|}
\hline \multirow{2}{*}{ Pertanyaan } & \multicolumn{3}{|c|}{ Hasil Jawaban Responden } \\
\cline { 2 - 4 } & \multicolumn{1}{|c|}{ IR\#4 IR\#5 } & IR\#6 \\
\hline & $\begin{array}{l}\text { mengenai beban } \\
\text { penyusutan. }\end{array}$ & mbak... & \\
\hline
\end{tabular}

Dari hasil wawancara diatas mengenai penerapan sistem akuntansi akrual dalam pengakuan dan pengukurannya, dapat dilihat bahwa untuk PP No. 24/2005 tentang SAP berbasis Cash Toward Accrual (CTA) belum sepenuhnya digunakan ini dapat dilihat dari belum diakuinya biaya penyusutan sehingga terjadi pengelembungan terhadap nilai aset. Dengan belum diakui biaya penyusutan pada aset daerah maka ini akan bertentangan dengan PP no. 71 tahun 2010 tentang SAP berbasis akrual.

Dengan demikian akuntansi berbasis akrual yang dilihat dari sistem pengakuan dan pengukuran akuntansi belum diterapkan sesuai dengan PP No. 24 Tahun 2005, maka dapat disimpulkan bahwa pemahaman pegawai publik mengenai sistem akuntansi akrual belum sepenuhnya dipahami. Pemahaman mereka mengenai sistem akuntansi akrual masih sangat sedikit, sehingga pelatihan dan bimbingan teknis untuk PP 71 tahun 2010 sangat diperlukan terutama di setiap SKPD - SKPD yang mengalami kesulitan selain itu perangkat pendukung seperti kebijakan akuntansi dan sistem akuntansi yang terkomputerisasi sangat dibutuhkan bagi staf akuntansi di setiap instansi.

\section{Informasi Penyebarluasan Laporan Keuangan}

Akuntansi keuangan daerah adalah suatu proses indentifikasi, pengukuran, pencatatan dan pelaporan transaksi ekonomi dari suatu daerah yang dijadikan sebagai informasi dalam rangka pengambilan keputusan ekonomi oleh pihak- pihak yang memerlukan (Pramono DKK, 2010).Dengan demikian maka informasi laporan keuangan perlu disebarluaskan terutama untuk kelompok utama pengguna anggaran, yang diantaranya adalah: (1) Masyarakat; (2) wakil rakyat, lembaga pengawas, dan lembaga pemeriksa; (3) pihak yang memberi atau berperan dalam proses donasi, investasi dan pinjaman, serta (4) pemerintah. Dalam kerangka konseptual akuntansi pemerintahan PP $24 / 2005$.

Seperti hasil wawancara berikut ini yang mempertanyakan "Apakah laporan keuangan yang digunakan untuk tujuan umum dalam pelaporan eksternal, berbeda dengan menerbitkan laporan dan disesuaikan untuk memenuhi kebutuhan kelompok pengguna tertentu?" IR\#1 Prov. Kalbar mengatakan:

"Sama lah mbak,.. kan kita ngak boleh buat laporan lebih dari satu.."

Hal senada juga disampaikan oleh IR\#2 yang mengatakan:

"Sama kita hanya buat satu saja kok"

Sedangkan untuk pertanyaan "Apakah laporan keuangan secara resmi disampaikan kepada lembaga legislatif dan pemerintahan?” Maka hasil wawancara yang disampaikan oleh IR\#2 menyampaikan:

"iya, setelah di audit dari BPK kita serahkan ke lembaga legislatif untuk di evaluasi.."

"dan juga ke SKPD-SKPD, serta ke Gubernur."

Hal yang sama juga diutarakan oleh IR\#3 Kab. Sanggau, yang mengatakan:

"iya,... setelah pemeriksaan baru di serahkan ke lembaga legislatif “...., dan setiap SKPD-SKPD pasti diberikan.."

Dari hasil wawancara tersebut maka untuk penyebarluasan informasi laporan keuangan kepada masyarakat umum belum pernah dipublikasikan baik itu di media cetak maupun website. Tetapi bagi masyarakat yang memerlukan laporan keuangan tetap akan di 
berikan. Sehingga informasi penyebarluasan masih terbatas pada para dewan, badan pengawas dan pemerintahan.

\section{Kendala - Kendala Penerapan Sistem Akuntansi Akrual}

Implementasi penerapan sistem akuntansi akrual masih jauh dari harapan untuk berhasil ini disebabkan oleh berbagai kondisi yang menjadi kendala. Dari hasil penelitian terdapat beberapa kendala yang ditemukan dalam kesiapan pegawai publik dalam penerapan akuntansi akrual yang diantaranya adalah sebagai berikut: Hasil wawancara yang disampaikan oleh IR\#2 Kota Pontianak yang mengatakan:

"Kita bagian akuntansi ini kesulitannya di SDMnya, terutama di akuntansi baru masuk belum lama sudah di pindahkan lagi, dan selalu seperti itu.. jadi kita yang mengajar kesulitan dan selalu dimulai dari nol lagi....."

Begitu juga dengan sistem komputerisasi yang belum digunakan seperti yang diungkapkan oleh IR\#2 Kota Pontianak:

"belum masih manual mbak, untuk sistem akuntansi tidak jalan tapi kalau sistem keuangan nya sih sudah..., nah sekarang saya lagi coba menugaskan ke staf saya untuk membuat alur akuntansi dengan menggunakan komputer tapi sampai sekarang belum selesai juga jadi kita memang masih manual."

Hal yang sama juga diutarakan oleh IR\#4 Kota Pontianak yang mengatakan:

"Kalau soal kendala ya itu tadi mbak.... dari SDM kita belum siap dan juga belum ada sosialisasi maupun bimtek..."

Ini tidak jauh berbeda seperti yang dikatakan oleh IR\#5 Prov. KalBar yang mengatakan bahwa:

"Menurut saya, yang menjadi kendala sebenarnya masalah waktu saja, dimana kami masih perlu waktu untuk belajar, selain itu kami juga diberikan pelatihan dan paling tidak ada pedomanlah mengenai basis akrual ini. Sedangkan untuk masalah SDM itukan akan terbentuk sendiri, jadi saya rasa tidak masalah karena kalau aturan sudah dikeluarkan maka siapapun SDM nya mau tidak mau harus dapat mengikuti.."

Dari informasi yang telah diuraikan diatas menunjukkan bahwa masih kurangnya kesiapan dari pemerintah untuk menerapkan sistem akuntansi akrual terutama dalam hal SDM dan Perangkat pendukungnya. Dimana diketahui bahwa SDM adalah pilar penyangga utama sekaligus penggerak roda organisasi dalam usaha mewujudkan visi, misi dan tujuan (Susilo 2002:3). Sehingga SDM merupakan faktor yang sangat penting untuk setiap usaha baik dalam suatu instansi pemerintahan dengan tujuan agar dapat menjalankan fungsi yang sebenar-benarnya. Dengan demikian faktor yang terpenting dalam penentu keberhasilan dari penerapan sistem akuntansi akrual khususnya di pemerintahan daerah kalimantan Barat yaitu adanya upaya pengembangan kapasitas sumber daya manusia secara serius dengan memberikan pelatihan-pelatihan mengenai sistem akuntansi akrual

\section{HASIL DAN PEMBAHASAN}

\section{Interpretasi Hasil Temuan}

Dari beberapa hasil temuan yang ditemukan dari hasil wawancara yang telah dibentuk pada tema wawancara pada tabel 4.1 sebelumnya, maka penulis akan mendiskripsikan temuan bukti dan membentuk suatu hipotesis kerja dari temuan tersebut dengan diaplikasikan ke dalam model Luder (1992) yang dapat dilihat pada tabel 4.3 berikut ini. 
Tabel 4.3. Aplikasi dari Model kontigensi Luder's

\begin{tabular}{|c|c|c|}
\hline Variabel konstektual & Hipotesis Kerja & Temuan Bukti \\
\hline Stimuli (Rangsangan) & - $\quad$ Krisis Ekonomi & $\begin{array}{l}\text { - Krisis Ekonomi (era } \\
\text { soeharto) }\end{array}$ \\
\hline \begin{tabular}{l}
\multicolumn{1}{c}{ Produsen } \\
informasi Akuntansi \\
Sektor Publik
\end{tabular} & $\begin{array}{ll}- & \text { Rekrutmen staf } \\
\text { - } & \text { Pelatihan staf }\end{array}$ & 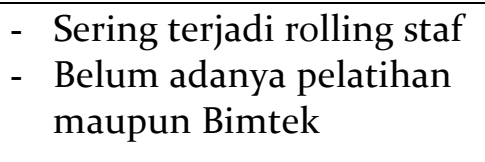 \\
\hline $\begin{array}{l}\text { Hambatan } \\
\text { Implementasi }\end{array}$ & $\begin{array}{ll}\text { - } & \text { Komitmen } \\
\text { - } & \text { Staf dengan } \\
& \text { kualifikasi yang } \\
& \text { diperlukan } \\
\text { - } & \text { Perangkat } \\
& \text { pendukung }\end{array}$ & $\begin{array}{l}\text { - } \text { Kurangnya dukungan dan } \\
\text { komitmen atasan } \\
\text { - } \text { Kurangnya staf dengan } \\
\text { kualifikasi yang } \\
\text { diperlukan } \\
\text { - } \\
\text { Perangkat pendukung } \\
\text { seperti kebijakan } \\
\text { akuntansi dan sistem } \\
\text { akuntansi yang } \\
\text { terkomputerisasi. }\end{array}$ \\
\hline
\end{tabular}

Dari tabel 4.3 tersebut maka berikut penjelasan dari setiap masing variabel konstektual yang diantaranya adalah :

1. Stimuli (Rangsangan)

Krisis Ekonomi : Berdasarkan temuan bukti yang dilakukan oleh Harun dan Robinson (2005) bahwa reformasi akuntansi sektor publik di Indonesia tidak dapat dipisahkan dari reformasi yang lebih luas yang terjadi pada perekonomian Indonesia dan sistem politik yang diikuti dengan pengunduran diri Soeharto pada tahun 1998. Dengan demikian tidak hanya pada krisis ekonomi saja tetapi juga gerakan pro-demokrasi dan tekanan dari donor internasional yang lebih merangsang upaya-upaya pemerintah Indonesia untuk dapat melakukan reformasi akuntansi sektor publik.

2. Produsen Informasi Akuntansi Sektor Publik

Rekrutmen Staf. Staf dengan kualifikasi yang diperlukan akan sangat mendukung didalam keberhasilan penerapan akuntansi akrual. Staf yang dimaksudkan khususnya adalah staf akuntansi yang dapat memahami dan mempraktekkan akuntansi akrual nantinya. Ini akan menjadi faktor yang sangat mempengaruhi bagi produsen informasi akuntansi sektor publik. Dimana rekrutmen staf akan menjadi faktor yang sangat mempengaruhi sikap dasar staf dalam kesiapannya untuk menerima perubahan dan lebih lanjut dalam melakukan pengembangan tentang sistem akuntansi akrual. Ini dapat dilihat dari temuan bukti bahwa sering terjadinya rolling pegawai khususnya staf akuntansi tanpa melihat apakah rekrutmen staf tersebut secara umum sudah memahami sistem akuntansi akrual, ini seperti yang dikatakan oleh salah satu informan yang mengatakan:

"kita di bagian akuntansi ini kesulitannya di SDMnya, terutama untuk staf akuntansi baru masuk dan belum lama sudah di pindahkan lagi dan selalu seperti itu.... jadi kita yang mengajar selalu kesulitan dan dimulai dari nol lagi."

Pelatihan staf. Untuk dapat meningkatkan kualifikasi staf akuntansi sesuai dengan yang diperlukan maka pelatihan dan bimbingan teknis mengenai akuntansi akrual sangat diperlukan saat ini sebagai bentuk dari kesiapan pemerintah untuk menerapkan akuntansi akrual. Dengan adanaya training maupun transfer knowledge 
mengenai akuntansi akrual akan memberikan pengaruh yang sangat signifikan terhadap keberhasilan penerapan akuntansi akrual di pemerintahan daerah khususnya Pemerintahan Daerah Kalimantan Barat. Ini seperti hasil wawancara dengan IR\#4 yang mengatakan:

“...dukungan saat ini yang diperlukan adalah menyiapkan SDM yang berkualitas serta segera untuk memberikan sosialisasi ke dinas-dinas...."

\section{Hambatan Implementasi}

Komitmen. Komitmen merupakan suatu hubungan individu (karyawan) dengan satuan kerja yang dapat menimbulkan suatu sikap dasar yang dipandang sebagai rasa saling keterikatan antara karyawan dangan organisasinya. Dimana dengan adanya dukungan yang kuat dari pimpinan akan menjadi suatu kunci keberhasilan dalam suatu perubahan. Komitmen akan menjadi suatu hambatan ketika pegawai publik merasa kurangnya dukungan dan komitmen dari atasan untuk melakukan perubahan yakni penerapan sistem akuntansi akrual. Dimana di pemerintahan daerah Kalimantan Barat dipandang masih kurang untuk komitmen dari atasan.

Kualifikasi staf. Kualifikasi staf akan menjadi hal yang paling mendasar dan signifikan dalam keberhasilan penerapan akuntansi akrual, karena staf akuntansi merupakan sikap dasar dan sangat mempengaruhi bagi produsen informasi dalam menghasilkan laporan keuangan pemerintahan dengan menerapkan sistem akuntansi sektor publik yang lebih informatif yaitu akuntansi berbasis akrual. Sehingga mereka dituntut untuk dapat memahami benar sistem akuntansi akrual.

Perangkat Pendukung. Perangkat pendukung akan sangat dibutuhkan dalam membantu sistem akuntansi pemerintahan agar dapat berjalan secara efektif. Dalam hal ini perangkat pendukung yang dimaksud dapat berupa sistem akuntansi yang terkomputerisasi dan kebijakan akuntansi. Karena dengan adanya perubahan sistem akuntansi pemerintahan yang lebih informatif sudah barang tentu harus didukung oleh perangkat pendukungnya.

Dari penjelasan setiap variabel kontekstual diatas maka gambar 4.1 berikut ini mengambarkan deskripsi dari adaptasi model kontigensi inovasi akuntansi sektor publik oleh Luder (1992): 


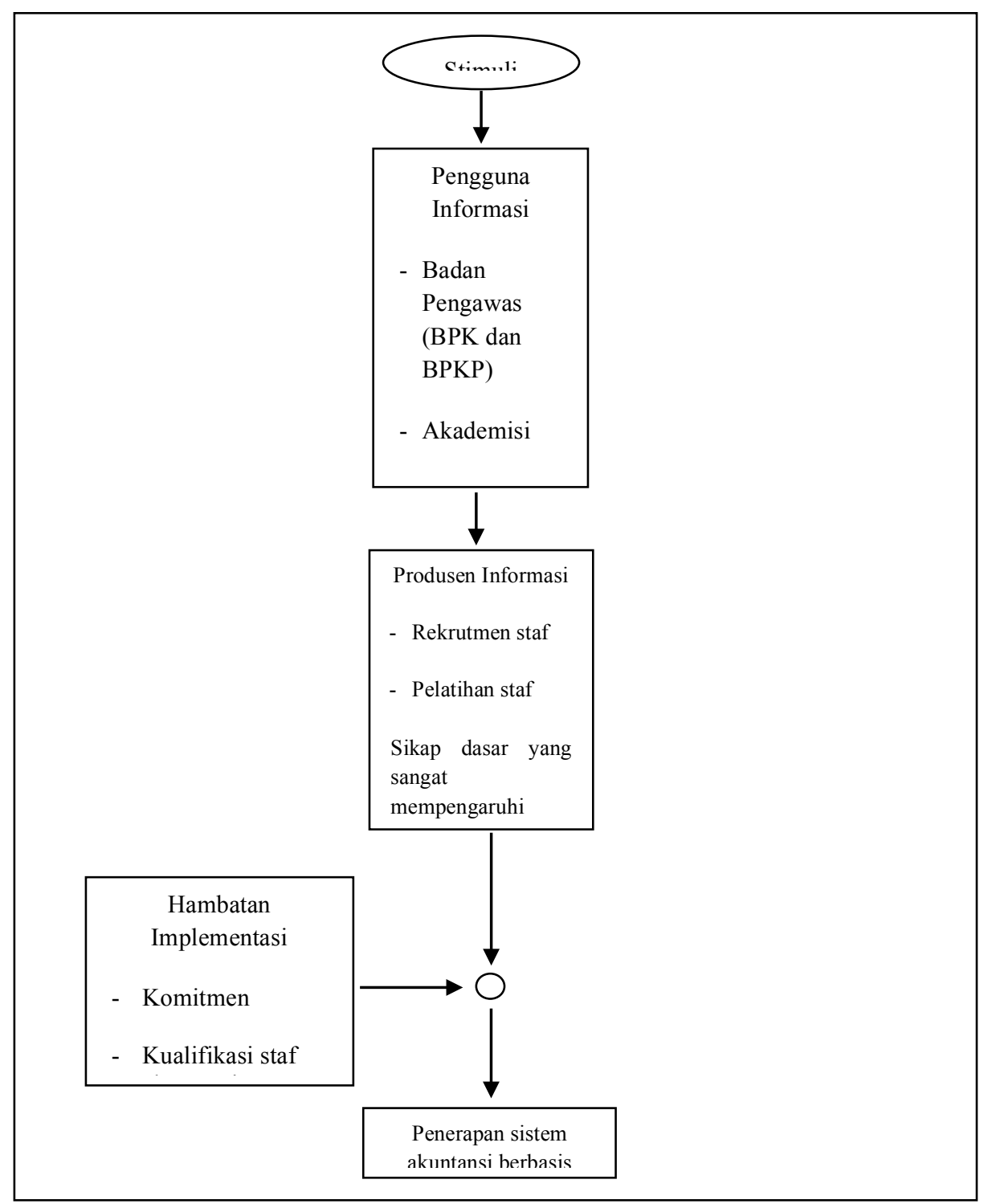

Gambar 4.1 Proses Model kontigensi inovasi akuntansi sektor publik (Adaptasi dari Luder 1992)

\section{Faktor - Faktor yang Mempengaruhi Keberhasilan Penerapan Akuntansi Akrual}

Berdasarkan hasil temuan bukti dari proses wawancara maka dapat disimpulkan ada beberapa faktor yang sangat berperan dalam keberhasilan penerapan sistem akuntansi akrual di pemerintahan daerah Kalimantan Barat yang diantaranya adalah :

1. Komitmen

Masih kurangnya komitmen dari atasan sehingga perlu dilakukan trik dan inisiatif sendiri dalam mencari informasi mengenai akuntansi akrual. Serta masih kurangnya dukungan yang diberikan seperti pelatihan, Bimbingan Teknis (Bimtek) maupun transfer knowlegde dari pihak independen yang memahami sistem akuntansi akrual. 
2. Kualitas SDM yang dibutuhkan

Masih kurangnya SDM yang memahami sistem akuntansi berbasis akrual, ini lebih dikarenakan sering terjadinya pergantian (rolling) pegawai terutama untuk staf akuntansi di setiap SKPD.

3. Perangkat Pendukung

Belum adanya perangkat pendukung seperti Sistem dan prosedur serta kebijakan akuntansi yang telah mengacu pada akuntansi berbasis akrual.

lingkungan pemerintahan daerah Kalimantan Barat masih jauh dari yang diharapkan, dimana diketahui penerapan akuntansi akrual sudah tidak lama lagi harus diterapkan yaitu tahun 2014 yang kurang lebih hanya tinggal 1 tahun lagi. Tetapi dari segi kesiapan pegawai publik masih sangat minim sekali terutama untuk SDM (staf akuntansi) dengan kualitas yang dibutuhkan, begitu juga dengan komitmen dari atasan dan perangkat pendukungnya dan ini semua juga tidak terlepas dari kesiapan pemerintah pusat dalam hal regulasi. Fenomena ini tidak jauh berbeda seperti yang diungkapakan oleh Harun dan Robinson (2005) ditingkat yang lebih luas yaitu Indonesia dimana dia menyatakan bahwa reformasi akuntansi akrual pada sektor publik di Indonesia telah menghadapi hambatan implementasi yang signifikan yaitu: masalah hukum, kurangnya staf yang berkualitas, rendahnya tingkat partisipasi dari parlemen dan warga negara.

\section{SIMPULAN}

Berdasarkan dari uraian bab-bab sebelumnya serta hasil analisis, maka didalam bab ini kesimpulan yang dapat ditarik dari penelitian ini adalah sebagai berikut:

1. Dengan menggunakan model luder (1992) yang diaplikasi ke dalam model kontigensi akuntansi sektor publik maka terbentuk hipotesis kerja dari temuan dengan kontekstual variabel diantaranya:

a. Stimuli : Krisis Ekonomi berdasarkan temuan bukti yang dilakukan oleh Harun dan Robinson (2005) bahwa reformasi akuntansi sektor publik di Indonesia tidak dapat dipisahkan dari reformasi yang lebih luas yang terjadi pada perekonomian Indonesia dan sistem politik yang diikuti dengan pengunduran diri Soeharto pada tahun 1998.

b. Produsen informasi akuntansi sektor publik : reformasi sistem akuntansi sektor publik akan sangat di pengaruhi oleh perekrutan staf khususnya staf akuntansi serta adanya pemberian pelatihan (training) mengenai sistem akuntansi akrual. Dimana rekrutmen staf akan menjadi faktor yang sangat mempengaruhi sikap dasar staf dalam kesiapannya untuk menerima perubahan dan lebih lanjut melakukan pengembangan tentang sistem akuntansi akrual.

c. Hambatan implementasi : ada beberapa hal yang di pandang dapat menjadi hambatan dalam penerpaan akuntansi akrual pada pemerintahan daerah kalimantan barat yang diantaranya adalah komitmen, staf dengan kualifikasi yang diperlukan serta perangkat pendukung.

2. Dari hasil temuan dan analisis data dapat disimpulkan bahwa ada beberapa faktor yang sangat berperan dalam keberhasilan penerapan akuntansi akrual di lingkungan pemerintahan daerah Kalimantan Barat yang diantaranya adalah :

a. Komitmen 
Masih kurangnya komitmen dari atasan sehingga perlu dilakukan trik dan inisiatif sendiri dalam mencari informasi mengenai akuntansi akrual. Serta masih kurangnya dukungan yang diberikan seperti pelatihan, Bimbingan Teknis (Bimtek) maupun transfer knowlegde dari pihak independen yang memahami sistem akuntansi akrual.

b. Kualitas SDM yang dibutuhkan

Masih kurangnya SDM yang memahami sistem akuntansi berbasis akrual, ini lebih dikarenakan sering terjadinya pergantian (rolling) pegawai terutama untuk staf akuntansi di setiap SKPD.

c. Perangkat Pendukung

Belum adanya perangkat pendukung seperti Sistem dan prosedur serta kebijakan akuntansi yang telah mengacu pada akuntansi berbasis akrual.

\section{PUSTAKA ACUAN}

A.Chaedar Alwasih, 2011, Pokoknya Kualitatif, Dasar-dasar merncang dan melakukan penelitian kualitatif, Pustaka jaya, Jakarta

Akhmad Solikin, 2006, "Penggabungan Laporan Keuangan dan Laporan Kinerja Instansi Pemerintah: Perkembangan dan Permasalahan”, Jurnal Akuntansi Pemerintah,Vol.2 No.2 Nopember 2006

Anik Nugrohowati, 2007, Penerapan Akuntansi Berbasis Akrual Di Organisasi Sektor Publik Di Yogyakarta, Jurnal Akuntansi dan Keuangan Sektor Publik, Vol.8, No.2, Agustus 2007.

Azhar, 2007, Faktor-faktor yang Mempengaruhi Keberhasilan Penerapan Permendagri Nomor 13 Tahun 2006 Pada Pemeirintah Kota Banda Aceh, FE USU, Medan.

Bambang Sancoko, 2008, "Kajian terhadap Penganggaran Berbasis Kinerja di Indonesia", Badan Pendidikan dan Pelatihan Keuangan, Departemen Keuangan RI.

Binsar, 2010, Penerapan Akuntansi Berbasis Akrual Di Sektor Pemerintahan Di Indonesia, Paper disampaikan pada Kongres XI IAI, Jakarta.

Bob Woworuntu, 2003, Determinan Kepemimpinan, Makara, Sosial Humaniora, Vol. 7, No.2.

Chairul imam, 2008, Evaluasi Strategi Penerapan Akuntansi Berbasis Akrual Pada Laporan Keuangan Pemerintah Menggunakan Model Kebutuhan Dasar, Skripsi, FE UI, Jakarta

Departemen Dalam Negeri, Republik Indonesia, 2007, Modul Akuntansi Pemerintah Daerah,

Denzin NK, Lincoln YS, 200o, The Discipline and Practice of Qualitatitive Research. Di dalam Denzin NK, Lincoln YS, eds. Handbook of Qualitative Research, Second edition, Thousands Oaks;SAGE.

Djam'an dan Komariah, 2011, Metodologi Penelitian Kualitatif, Alfabeta, Bandung

Elya, Lisnawati, Nila, 2010, Pengaruh Independensi, Gaya Kepemimpinan, Komitmen Organisasi, dan Pemahaman Good Governance Terhadap Kinerja Auditor Pemerintahan (Studi pada Auditor Pemerintahan BPKP Perwakilan Bengkulu), SNA, Purwokerto.

Emzir, 2010, Metodologi Penelitian Kualitatif Analisis Data, RajaGrafindo Persada, Jakarta.

Halim, Abdul, 2004, Akuntansi Sektor Publik : Akuntansi Keuangan Daerah, Edisi Revisi, Salemba Empat, Jakarta.

Harun El-Raseed, Peter Robinson, 2005, Implementing Accrual Regime in the Context of the Indonesian Public Sector Accounting Reform, Simposium Riset Ekonomi II, Surabaya. 
International Federation of Accountants (IFAC), Public Sektor Committee, 2003, Study 14, Transition to the Accrual Basis of Accounting. Guidance for Goverments and Goverment Entities. Second Edition.

James L. Chan, Rowan H. Jones, and Klaus G. Luder, 1996, Modeling Governmental Accounting Innovations; an Assesment and Future Research Directions, journal research in govermental nonprofit accounting, Vol 9, p 1-19

Keputusan Menteri Dalam Negeri Nomor 29 Tahun 2002 Tentang Pengelolaan Keuangan Daerah.

Klaus G. Luder, 1992, A Contingency Model of Governmental Accounting Innovations in the Political-Administrative Environment, Research in Governmental and Nonprofit Accounting, Vol.7, pages 99-127.

Komite Standar Akuntansi Pemerintahan, 2006, Memeorandum Pembahasan Penerapan Basis Akrual Dalam Akuntansi Pemerintahan Di Indonesia, Bahan Bahasan untuk Limited Hearing, Jakarta.

Mahmudi, 2010, Manajemen Kinerja Sektor Publik, Edisi Kedua, STIM YKPN, Yogyakarta.

Moleong, 2010, Metodologi Penelitian Kualitatif, Edisi Revisi, PT Remaja Rosdakarya, Bandung

Osborne, David and Ted Gaebler, 1992, Reinventing Goverment: How the Entrepreneurial Spririt Is Tranforming The Public Sector, New York: Penguin Books Inc.

Otley, D, 1980, "The Contingency Theory of Management Accounting: Achievement and prognosis" Accounting Organizations and Society, pp 413-428.

Patton, M.Q, 1990, Qualitative Evaluation and Research Method. 2nd edition, Newbury Park, Sage

Peraturan Menteri Dalam Negeri Nomor 13 Tahun 2006 Tentang Pedoman Pengelolaan Keuangan Daerah

Peraturan Menteri Dalam negeri Nomor 59 Tahun 2007 Tentang Pedoman Pengelolaan Keuangan Daerah, Perubahan atas Peraturan Menteri Dalam Negeri Nomor 13 tahun 2006.

Peraturan Pemerintah Republik Indonesia No. 24 tahun 2005 Tentang Standar Akuntansi Pemerintahan.

Peraturan Pemerintah Republik Indonesia No. 71 Tahun 2010 Tentang Standar Akuntansi Pemerintahan Berbasis Akrual.

Phetphrairin Upping, Judy Oliver, 2011, Accounting Change Model For The Public Sector: Adapting Luder's Model for Developing Countries, International Review of Business Research Papers, Vol 7. No. 1. Pp. $364-380$.

Pramono, Yanuar, Icuk Rangga, 2010, Pengelolaan Keuangan Daerah,Salemba Empat, Jakarta.

Robbins, Stephen, 2001, Prilaku Organisasi : Konsep, Kontroversi, Aplikasi. Edisi Bahasa Indonesia. PT Prenhallindo, Jakarta.

Robinson,P \& Harun 2004, Reforming the Indonesian Public Sector: The Introduction of Accrual Accounting, In Forth Asia Pacific Interdisciplinary Research in Accounting Conference, Singapura.

Susilo W, 2002, Audit Sumber Daya Manusia, Penerbit Gema Amini, Jakarta

Soeratno, Lincolin Asrsyad, 20o8, Metodologi Penelitian Untuk Ekonomi dan Bisnis, UPP STIM YKPN, Yogyakarta.

Thomas H. Beechy, 2007, Does Full Accrual Accounting Enhance Accountability, the innovation Journal, The Public Sector Innovation Journal, Vol 12 (3).

Tohirin, 2012, Metode Penelitian Kualitatif dalam Pendidikan dan Bimbingan Konseling, PT Raja Grafindo Persada, Jakarta

Undang - Undang Republik indonesia No. 1 Tahun 2004 Tentang Perbendaharaan Negara

Undang - Undang Republik Indonesia No. 17 Tahun 2003 Tentang Keuangan Negara. 
Undang - Undang Nomor 15 Tahun 2004 Tentang Pemeriksaan Pengelolaan dan Tanggungjawab Keuangan Negara.

Zakiah Saleh, 2007, Perceptions on Factors That Influence The Development of Governmental Accounting in Malaysia,Faculty of Business and Accountancy, University of Malaya, Kuala Lumpur, Malaysia. 